\title{
Carreras de la memoria: corporalidad, dinamismo y performatividad en Campo de Mayo de Félix Bruzzone
}

\section{Careers of Memory: Corporeality, Dynamism and Performativity in Campo de Mayo by Félix Bruzzone}

\begin{abstract}
Resumen
Entre el heterogéneo corpus de obras escritas por hijos de desaparecidos argentinos uno de los aportes más interesantes y originales son los textos de Félix Bruzzone. Este artículo se propone como objetivo encuadrar las características principales del estilo del autor para luego analizar su última novela Campo de Mayo (2019). La obra nace en realidad en otra dimensión textual, la de la performance, por esta razón primero se abarcarán las peculiaridades de esta textualidad, para luego reflexionar sobre los mecanismos que intervienen en el pasaje a la novela. Se demostrará que en la novela quedan muchos elementos de la performance, todos vinculados a la temática de la búsqueda de padres desaparecidos, que hacen que la dimensión corporal y dinámica del hipotexto se quede en su 'novelización' para armar un discurso que a través de la corporalidad del protagonista pone en escena todas las contradicciones y la paradojas que esta búsqueda imposible implica, sirviéndose de la imagen textual del cuerpo en movimiento para dar cuenta de las complejas dinámicas de definición identitaria que atañen a los hijos de desaparecidos.
\end{abstract}

Palabras claves Félix Bruzzone; literatura de hijos de desaparecidos; literatura y performance; dinamismo; literatura corporal.

\begin{abstract}
In the heterogeneous corpus of works published by sons of Argentinean desaparecidos one of the most interesting and original contribution are the texts written by Félix Bruzzone. The aim of this article is to outline the main characteristics of the author's style and then to analyse his
\end{abstract}


last novel Campo de Mayo (2019). The novel actually originates as another type of text, a performance, so first of all, the peculiarities of this textuality will be identified, in order to reflect on the mechanisms that intervene when a performance is transposed into a novel. It will be demonstrated that the novel keeps many elements of the performance, all linked to the theme of the search for disappeared parents, that ensure that the dynamic corporeal characteristic of the hipotext is kept in its novelisation, in order to create a discourse that through the body of the protagonist displays all the contradictions and paradoxes that this impossible search implies, using de textual image of the moving body to give an account of the complex dynamics of identity definition concerning sons of desaparecidos.

Keywords Félix Bruzzone; desaparecidos' sons literature; literature and performance; dynamism; corporeal literature.

Entre el vasto y heterogéneo conjunto de autores que configuran la narrativa de los HIJOS $^{1}$ de desaparecidos argentinos una de las voces más interesantes es la de Félix Bruzzone. La publicación del libro de cuentos 76 y, sobre todo, de la novela Los topos (ambos publicados en 2008), se impusieron como un verdadero 'giro' en este tipo de narrativa, estimulando una serie de nuevos acercamientos teóricos a las narraciones producidas por esta generación.

Las características que motivan esta resonancia de las primeras publicaciones de Bruzzone residen no tanto en la materia narrada, sino en el estilo elegido para narrarla. De hecho, Bruzzone toma un leitmotiv que a menudo recurre en la narrativa de los HIJOS, el de la búsqueda (de los padres desaparecidos, de los hermanos apropiados, de noticias y, definitivamente, de la propia identidad), abarcándolo sin embargo de una manera extremadamente particular, a través del prisma de la parodia y de la incorrección.

No se trata de una novedad absoluta, otros HIJOS habían elegido un posicionamiento que podemos definir 'irriverente' (Sarlo 147) con respeto a su historia familiar: quizás el ejemplo más contundente es la película Los Rubios,

${ }^{1} \mathrm{Al}$ escribirlo con mayúsculas me refiero a la distinción operada por Teresa Basile entre el término 'hijos', que se refiere genéricamente a un lazo familiar, y 'HIJOS', que alude a la generación especifica de los hijos de desaparecidos en Argentina, más allá de su configuración institucional (Basile 19). 
dirigida por Albertina Carri y estrenada en 2003, en la cual, por primera vez, se pone en escena el conflicto entre la búsqueda de los padres y aquella de la identidad individual de los hijos. La irreverencia de la película de Carri reside en el hecho de que, a través de precisas elecciones estilísticas, la directora logra desplazar la voz de la generación de los padres, encarnada oblicuamente en los testimonios de sus compañeros de militancia. Las entrevistas a estos sujetos están grabadas de manera borrosa y se resuelven en comentarios bastante fútiles, dejando así el papel protagónico a la presencia de la actriz que interpreta a la misma Carri, la cual, aunque siempre de espalda, domina la escena, instalándose en un lugar autoritario desde el cual puede manipular y recortar el relato de los testigos. La voz testimonial de la hija se desplaza así hacia la ficción -también a través del recurso a escenas animadas realizadas con muñecos Playmobil- sin desembocar totalmente en la misma. En la película aparecen muchas veces las máquinas de grabación cinematográfica, la misma protagonista rebobina cintas o saca y pone VHS de los testimonios de los compañeros de los padres. Los mecanismos de la memoria quedan así completamente expuestos, especialmente cuando la misma Carri aparece en pantalla, desdoblando su personaje entre la verdad testimonial de su presencia y aquella ficcional de su alter ego. Los rubios genera un corte con respeto a los patrones típicos de la búsqueda de padres desaparecidos, y al mismo tiempo inaugura una nueva voz, que a través de una actitud provocadora adquiere en control total de su narración (Basile 133-136).

Bruzzone, especialmente en Los topos, lleva esta irreverencia hasta el paroxismo, convirtiéndola en un actitud paródica que, si bien pone en escena todas las herramientas y los recursos típicos de la narración de la búsqueda (entrevistas a compañeros de militancia de los padres, militancia en organizaciones de derechos humanos — especialmente H.I.J.O.S. $\perp^{2}$ y visitas a los lugares de detención, sólo para mencionar algunos), al hacerlo los resignifica, proporcionando un relato que

${ }^{2}$ Hijos e Hijas por la Identidad y la Justicia contra el Olvido y el Silencio (H.I.J.O.S.) es una organización de Derechos Humanos, fundada en 1995, cuyo objetivo es reunir hijos e hijas de víctimas del terrorismo de Estado durante la última dictadura cívico-militar argentina (19761983). 
desvía de las matrices convencionales y termina configurando un diferente tipo de subjetividad, más compleja, capaz de dar cuenta de todos los matices identitarios contradictorios que coexisten en un individuo que tiene que medir con la ausencia de padres que el Estado hizo desaparecer.

En su presentación de Los topos, titulada Plan de evasión (2009), Nicolás Prividera elabora una taxonomía de las actitudes que los HIJOS muestran con respeto a la generación de sus padres, y distingue entre hijos 'replicantes', que continúan el legado paterno, 'frankensteinianos', que pretenden escapar del mismo $\mathrm{y}$, precisamente a partir de la novela de Bruzzone, termina definiendo un tercer tipo de hijos, los 'mutantes', es decir los que, aunque asuman su origen de 'hijo de desaparecidos', buscan rutas de escape en el presente o en el futuro, más que en el pasado.

La tripartición elaborada por Prividera resuena en la distinción operada por Gabriel Gatti (2011) entre 'narrativa del sentido' y 'narrativa de la ausencia de sentido'. Si la primera busca maneras para curar las heridas y reanudar los vínculos quebrados por la desaparición, la segunda se niega a este tipo de operación y, en contra, prefiere habitar la catástrofe del sentido y hablar desde la misma. En este sentido, los hijos 'replicantes' pertenecerían a la 'narrativa del sentido', mientras aquellos 'frankesteinianos' y 'mutantes' a aquella de la 'ausencia de sentido'. Ambos estudios concuerdan en una evaluación más positiva de la segunda actitud, aquella que de alguna manera pone en tela de juicio la recuperación acrítica del legado de militancia paterno, y en efecto los aportes artísticos más interesantes producidos por hijos de desaparecidos generalmente se encuadran en estas coordenadas. $^{3}$

Desde estas perspectivas el sujeto que toma la palabra en estos textos es el hijo huérfano, el "post-huérfanito paródico" o el "bastardo inapropiado" (Gatti),

${ }^{3}$ Además de los textos de Bruzzone y de la película de Carri otros ejemplos son Soy un bravo piloto de la nueva China (2011) de Ernesto Semán, Diario de una princesa montonera (2012) de Mariana Eva Pérez, ¿Quién te crees que sos? (2012) de Ángela Urondo Raboy y Aparecida (2015) de Marta Dillon, sólo para citar algunos. 
verdaderas encarnaciones de aquel carácter 'mutante' individuado por Prividera, para asumir un papel protagónico en su historia, desviando los discursos y las prácticas típicos de las políticas de la memoria, sin salirse por completo de los mismos. Recordamos que se están parodiando estos discursos y, como señaló Genette $^{4}$ (1989), una parodia es una repetición con alteración, una transformación lúdica cuyo objetivo es invertir la significación del objeto parodiado, sin deshacerse del mismo.

Es como si estos sujetos, estos huérfanos que no se acomodan al discurso que grupos como H.I.J.O.S. les proporcionan, reclamaran su momento para hablar, y lo hicieran desde los márgenes de las políticas memoriales de su tiempo.

El síntoma más evidente $\mathrm{y}$, también, interesante de este discurso es la abundancia, en los textos de Bruzzone, de sujetos que, de una manera u otra, escapan de las mallas del tejido social, sujetos marginales que ahora toman la palabra para decirse en su heterogénea y múltiple identidad. Que se trate de mendicantes, de travestis o de prostitutas, los habitantes del universo literario de Bruzzone siempre son 'ovejas negras' en una sociedad que quiere eliminarlos, o por lo menos que elige no orientar su mirada hacia ellos, y es desde este peculiar posicionamiento, excéntrico y marginal, que arman un discurso identitario que se mueve entre la dimensión racional e irracional, entre el cuerpo y la mente, entre la realidad y el onírico, en un espacio textual que contamina varios géneros y estilos, desde el realismo hasta la ciencia ficción, desde el testimonio hasta la novela de aprendizaje.

Desde el punto de vista estilístico y lingüístico en las novelas y los cuentos de Bruzzone se destacan algunas características que, a lo largo de la carrera del

${ }^{4}$ Gérard Genette dedica uno de sus ensayos más conocidos, Palimpsestos (1989), al estudio de las diferentes formas de hipertextualidad, es decir la relación que une un texto B (denominado 'hipertexto') a un texto A ('hipotexto') sin configurarse en términos de comento. El teórico francés señala dos principales prácticas hipertextuales: la imitación, es decir la apropiación del estilo del hipotexto en la escritura del hipertexto, y la transformación, que consiste, en contra, en la apropiación del contenido del hipotexto, trasformado según reglas formales o intenciones semánticas, o directamente traspuesto en otro estilo. En este segundo caso se encuadra la parodia, que según Genette se realiza cuando un hipertexto transforma los contenidos de un hipotexto con intención lúdica, sin deshacerse así de los mismos, sino aplicándolos a un contexto diferente que hace que los contenidos dejen de parecer serios y áulicos, para convertirse en divertidos y irónicos. 
escritor, se han convertido en marcas distintivas, como por ejemplo el empleo intensivo del estilo indirecto y indirecto libre, el predominio de frases paratácticas y la masiva presencia en el texto de interjecciones (muy a menudo blasfemas). A estos elementos se suma la particularidad de la variante lingüística castellana elegida por Bruzzone, es decir el lunfardo, ${ }^{5}$ cuyo vocabulario impregna las obras del autor. Todas estas características concurren a configurar un estilo que encuentra en la adherencia al habla cotidiana de los tipos humanos representados tanto su función como su marca distintiva.

Este es entonces el marco estilístico y de contenido que encuadra la producción literaria de Félix Bruzzone desde sus primeras obras, pasando por la novela Las chanchas (2014) y terminando con su última publicación: Campo de Mayo (2019), que sin embargo presenta algunos rasgos de diferenciación con respeto a las obras anteriores del autor. Si en otros textos de Bruzzone la dimensión biográfica se encubre detrás de las estrategias ficcionales puestas en escena y apenas comentadas, Campo de Mayo, en virtud de su peculiar proceso de gestación en el campo de la performance, se construye en la tensión entre encubrimiento narrativo, reanudándose así a los textos anteriores, y descubrimiento en lo performativo, marcando entonces algo como un 'giro' en la producción del autor. Este carácter novedoso justifica el interés en reflexionar sobre la novela, en particular enfatizando la importancia que la dimensión dinámica y corporal adquiere en la misma tanto a nivel temático, como estructural.

\section{Hipotextos}

${ }^{5}$ El lunfardo es una jerga originada en Buenos Aires y su conurbación (aunque sus estudiosos concuerdan en el papel fundamental que las áreas urbanas de Rosario y Montevideo tuvieron en su desarrollo ya desde el primer periodo), nacida por la masiva presencia de inmigrados europeos, especialmente italianos y españoles, en la ciudad. El lunfardo se caracteriza por un vocabulario especifico, diferente del castellano estándar, cuyos lemas provienen de varios otros idiomas o de otras jergas: principalmente del italiano, pero también del francés, del inglés, del portugués, de lenguas indígenas (especialmente quechua, guaraní y mapuche), del Bantú africano y del lenguaje gauchesco. En principio empleado por la delincuencia urbana, el lunfardo se difundió rápidamente tanto por la habitualidad de su uso, como, y especialmente, por su empleo en las letras de tango. Hoy en día muchos términos del lunfardo forman parte del lenguaje natural de casi toda Argentina, Uruguay y, en menor medida, Paraguay. 
La novela nace, como ya se adelantó, en otra dimensión textual: la de la performance. En 2013 la directora Lola Arias organizó un ciclo de conferencias, titulado Mis documentos, cuyo proyecto era crear un espacio en el que varios artistas de diferentes disciplinas pudieran exhibir sus propias investigaciones, sus experiencias y sus inquietudes.

El intento del proyecto, como comenta Arias en la página $w_{e b}{ }^{6}$ dedicada, era "hacer visibles esas investigaciones que a veces se pierden en una carpeta sin nombre en la computadora". Se trata entonces de un conjunto de conferencias no académicas donde los varios sujetos que hablan exponen materiales que tradicionalmente serían considerados inacabados, work in progress, con el objetivo de transformar el discurso en obra de arte.

Este tipo de inquietud se relaciona con lo que Laddaga identifica como un creciente proceso de espectacularización del escritor (Laddaga, 2010), que se concretiza en dispositivos narrativos como, por ejemplo, la exposición de las etapas de desarrollo de la escritura o las relaciones con las fuentes. Este fenómeno de proliferación de formas narrativas (Keizman 2) encuentra su contrapunto en toda una serie de reflexiones críticas y teóricas que tienen que ver con la creciente difusión en las últimas tres décadas de las teorías de crítica genética, ${ }^{7}$ y sobre todo con el auge de las narrativas del yo y de los géneros (auto)referenciales, síntoma del así llamado "giro subjetivo"8 (Sarlo) o "giro afectivo" (Arfuch, Vida) y bien

${ }^{6}$ www.misdocumentosciclo.blogspot.com.ar [consultado el 11 de mayo de 2020]

${ }^{7}$ La crítica genética es una línea de investigación filológica que nace a finales de los años Setenta en Francia, Alemania e Italia, cuyo objeto de estudio son los materiales textuales que preceden al texto final de una obra escrita por un autor. Teorizada por el crítico francés Louis Hay en 1979, la crítica genética tiene como objetivo producir una edición de una obra que muestre todos los materiales pre-textuales (avant-texte), estudiando las variantes que intervinieron entre estos últimos y el producto final editado. En esta perspectiva el verdadero objeto de estudio deja de ser el texto, reemplazado por el interés en el proceso de escritura que lo precede.

${ }^{8}$ Según Sarlo, cuando en los años Setenta y Ochenta se produce el fenómeno denominado "giro lingüístico" (linguistic turn), es decir cuando - a partir de las teorías elaboradas por Wittgenstein en su Tractatus logico-philosophicus (1921) - en el campo de la filosofía se produce un sustancial cambio metodológico que afirma que el trabajo conceptual y teórico no puede lograrse sin un análisis previo del lenguaje, paralelamente se impone el "giro subjetivo". Según la estudiosa argentina este fenómeno coincide con un reordenamiento ideológico y conceptual de la sociedad, concentrado sobre los derechos y la verdad de la subjetividad, y que encuentra su contrapunto en 
sintetizadas por el concepto de 'espacio biográfico' acuñado por la crítica argentina Leonor Arfuch (Espacio, Vida), definido como una "espacio/temporalidad" (Vida 11) que no se configura como una simple acumulación de géneros afines, sino "un horizonte de inteligibilidad para dar cuenta $[. .$.$] de lo que aparecía como una$ verdadera reconfiguración de la subjetividad contemporánea“ (29).

Una de las exposiciones del proyecto de Arias fue la de Bruzzone, titulada Campo de Mayo. Una conferencia perfomática, que constituye el embrión de la novela recién publicada. Reflexionando sobre la relación entre la performance y los textos publicados por Bruzzone, Keizman evidencia como, mientras en Los topos, Las chanchas y los cuentos de 76 el discurso referencial se disloca por líneas ficcionales, de carácter lúdico, imaginativo y no-realista, el discurso de la performance "no ha sido expuesto al trabajo fuerte de imaginería ficcional que ya es un sello de estilo del autor" (Keizman 3). La conferencia de Bruzzone se funda entonces sobre la elaboración de un discurso reflexivo y autobiográfico, que encuentra su característica esencial en el hecho de ser, como comenta el mismo autor durante la performance, "un proyecto permanente de narración incompleta" $\mathrm{y}$, como se comentará, la novela mantiene este carácter abierto, dinámico e inacabado. ${ }^{9}$

El argumento de la performance se saca de la experiencia directa del autor: Bruzzone, de hecho, relata de cuando se mudó, sin saberlo, a pocas cuadras de Campo de Mayo, una de las más grandes guarniciones militares argentinas que fue también empleada como centro clandestino de detención durante la última dictadura cívico-militar, ${ }^{10}$ y que fue el último lugar donde estuvo detenida la madre del autor antes de su desaparición.

una análoga renovación en la sociología de la cultura y en los estudios culturales, donde los sujetos vuelven a tomar el lugar central que, hacia aquel momento, estaba ocupado por las estructuras (Sarlo 22).

${ }^{9}$ En efecto, a evidenciar esta condición de permanente desarrollo, algunas partes del trabajo que desemboca primero en la performance y después en la novela ya habían aparecido previamente en los fragmentos de "Mil palabras", publicados por la revista Otra parte, y en la crónica "Campo de Mayo: cómo quebrar a un rugbier" escrita para la revista Anfibia.

${ }^{10}$ Campo de Mayo es una guarnición militar, con una superficie de $42 \mathrm{~km}^{2}$, ubicada en el noroeste de la ciudad de Buenos Aires. Inmediatamente después del golpe militar de 24 de marzo de 1976 
Desde esta inconsciente cercanía con un lugar profundamente marcado por su historia Bruzzone desencadena una narración que, al centrarse en la búsqueda de un contacto con la figura materna, combina la actitud 'detectivesca' e histórica típica de los relatos de búsqueda con estrategias artísticas y literarias, centradas más en el presente que en el pasado. Por esta razón el núcleo temático de la búsqueda, durante la performance, muy a menudo se desvía hacia otra investigación, que pone en el centro la especialidad física y social de Campo de Mayo, cartografiándolo e indagando las relaciones que el autor, su familia y otras personas entrevistadas mantienen con el lugar. En este sentido, tiempo y espacio se convierten en las dos coordenadas que estructuran la forma y los contenidos del relato, y que proporcionan un discurso en tensión entre un pasado inalcanzable y un presente que no logra deshacerse de las huellas de lo que pasó. El espacio de Campo de Mayo se convierte en la concreción de esta superposición, un lugar donde el pasado y presente dialogan estrechamente en un movimiento de acercamiento y aproximación, pero que nunca se resuelve en una coincidencia.

El discurso de Bruzzone empieza en el ámbito familiar, con la proyección en una pantalla de una foto de la madre, para luego abrirse paulatinamente a una dimensión más colectiva a través del empleo de fotos y videos de las rutas que atraviesan el Campo y de los recorridos llevados a cabo por el mismo autor, acompañados por las voces y las caras de otros sujetos entrevistados durante estos recorridos. La atención del autor se desplaza entonces desde el pasado hacia el presente y, también, el futuro del lugar, centrando la atención no tanto sobre la guarnición militar instalada en Campo de Mayo, como en los espacios públicos del lugar.

El movimiento desde la intimidad hacia la colectividad es evidente también en la organización espacial de la performance. De hecho, aunque el centro de la atención es siempre la figura del escritor que lee sentado a una mesa lateral mientras

empezó a funcionar como centro de detención clandestina. Se estima que miles de los que fueron detenidos en el así llamado 'campito' fueron desaparecidos a través de los numerosos vuelos de la muerte que partían del campo. 
se proyectan los materiales visuales ya mencionados, la performance prevé también la duplicación de la escena a través de la presencia de un actor que corre sobre otra mesa, detrás de la cual se proyecta el video de un paisaje en movimiento.

La presencia del actor cobra importancia especialmente hacia el final del discurso de Bruzzone, cuando el autor se pregunta qué hacer con todo el material encontrado y elaborado para la performance, y se propone la creación de un personaje que precisamente corre infinitamente por las rutas de Campo de Mayo, en un movimiento que "no es el movimiento del flâneur, sino un movimiento acelerado, un desplazamiento que permite aprehender sin pausa" (Keizman 6).

La novela termina 'no terminando': Bruzzone proyecta su narración performática hacia una posible narración futura, de carácter marcadamente ficcional al presuponer la creación de un personaje en el que condensar todas las temáticas de la performance. La elección de la forma para esta nueva narración tarda algunos años, hasta que, en 2019 (seis años después de la primera performance) Bruzzone la publica en forma de novela.

Sin embargo, antes de fijar la atención sobre la novela recién publicada, cabe subrayar, aunque de manera rápida y procediendo por macrocategorías, algunas de las peculiaridades de la forma de la performance y, más en general, del uso performativo del lenguaje.

Reflexionado sobre estas temáticas, Gina Carolina Brijaldo evidencia cómo el concepto de 'performance' conlleva una doble concepción del papel de la escritura performativa: por un lado, la forma de la performance remite a una precisa condición ontológica, que Brijaldo explicita a través de las consideraciones del actor, director y performer brasileño Renato Cohen: ${ }^{11}$

El performance está ontológicamente conectado a un movimiento mayor, una manera de ver el arte; Un live art. Un live art es el arte en vivo y también el arte vivo. Es una forma de ver arte en el que se procura una

${ }^{11}$ Cito la traducción al español del texto original en portugués elaborada por la misma Brijaldo (113). 
aproximación directa con la vida, en que se estimula lo espontáneo, lo natural, en detrimento de lo elaborado, lo ensayado. (Cohen 38)

"Arte en vivo" y "arte vivo": desde el punto de vista ontológico la forma artística de la performance se caracteriza por la adherencia al fluir natural de la vida, de manera muy a menudo espontánea y azarosa, deshaciéndose entonces de cualquier estructura fija planteada a priori.

Por el otro lado Brijaldo evidencia también el valor epistemológico de la performance, que abre el campo de posibilidades teóricas y configura un espacio donde se cruzan de manera altamente fructífera saberes interdisciplinares y medios expresivos diferentes, proporcionando un conocimiento que, como señala Pablo Assumpçao, se adquiere y se negocia en la dimensión corporal, y que impone armar un nuevo pensamiento sobre el mismo, reconociendo el aporte de la práctica artística a la teoría:

El entendimiento del performance como episteme - como "un modo de conocer" la realidad - obliga a cuestionar la misma naturaleza del conocimiento y de la investigación, y sugiere que la práctica y la creatividad artísticas son operadores centrales en la llamada actividad teórica. (Assumpçao, en línea)

En este sentido, la concepción epistemológica que funda la praxis de la escritura performativa se centra en el cuerpo como vector de conocimiento de la realidad de la cual se escribe. Es una escritura que no sólo relata la experiencia, sino que acontece en la misma, y replantea constantemente los posicionamientos teóricos que la soportan: "Escribir performativamente también significa entender que la teoría es cambiante, dinámica, que se mueve al ritmo de los dispositivos performáticos" (Brijaldo 114), y que impone un necesario replanteamiento de las subjetividades involucradas (Culler 94), a partir de la del autor, cuya autoridad ya 
cuestionaron Foucault ${ }^{12}$ (¿Qué es un autor?) y Barthes, este último llegando a declarar su metafórica muerte, ${ }^{13}$ difuminando su imperio sobre el texto en favor de una nueva instancia de significación, es decir aquella del lector que lo activa a través de su actividad de lectura. Más aún en el caso de un uso performativo del lenguaje:

Al señalar la muerte del autor y el nacimiento del lector, Barthes revela una característica más de lo performativo: lo que las palabras hacen es producir una subjetividad, es decir, una forma concreta de ser consciente y de entender el mundo. (Centre de Creació del Cos I el Moviment, 2012: en línea)

El texto performativo configura entonces una dimensión totalmente abierta y tensa hacía el otro, el lector/espectador que, como bien plantea Bourriaud, deja de ser un mero 'visitante' al participar activamente en la construcción de sentido de la obra (Bourriaud, 2008). La escritura performativa se convierte en un campo de interacción entre sujetos, deconstruye la idea de 'genio creador' y la suplanta con la búsqueda de nuevas maneras de expresión y experimentación que se juegan en la tensión intersubjetiva, en el establecimiento de vínculos colectivos entre actores

${ }^{12} \mathrm{El}$ análisis de Foucault, desarrollado en la ponencia Qu'est-ce que qu'un auteur? expuesta en la Société française de Philosophie en 1969, busca encontrar los lugares en que permanece la figura del autor después de la constatación de su muerte por Barthes. Foucault teoriza la existencia de una función-autor, diferente del sujeto-autor empírico, que sigue presente en distintos niveles discursivos, precisamente cuatro: el nombre del autor, la relación de apropiación que la funciónautor conlleva con respeto al texto, la relación de atribución que individua en el autor el lugar originario de la escritura desde el cual se puede explicar la obra, y la posición del autor en el texto, señalada a través de marcas gramaticales (pronombres, declinaciones verbales, etc.) que remiten no al escritor, sino a su alter ego textual. Es en esta escisión entre escritor y alter ego que Foucault encuentra el lugar de la función-autor, quitando entonces al sujeto-autor empírico su dominio sobre el texto (Foucault, ¿Qué es un autor?).

${ }^{13} \mathrm{Al}$ declarar la muerte del autor, Barthes señala el carácter perfomativo y transitivo del lenguaje. Según el filósofo no es una singla persona, el autor, a entregar sentido a la obra, sino es el lector a recoger la multiplicidad contenida en los textos literarios. El origen de una obra literaria deja así de concebirse en la dimensión personal del autor, para desplazarse en "un espacio de múltiples dimensiones en el que se concuerdan y se contrastan diversas escrituras, ninguna de las cuales es la original: el texto es un tejido de citas provenientes de los mil focos de la cultura" (Barthes 69), cuyo depositario es definitivamente el lector. 
diferentes, adquiriendo así un valor no tan sólo estético, sino también ético y político:

La posibilidad de un arte relacional - un arte que tomaría como horizonte teórico la esfera de las interacciones humanas y su contexto social, más que la afirmación de un espacio simbólico autónomo y privado, da cuenta de un cambio radical de los objetivos estéticos, culturales y políticos puestos en juego por el arte moderno. [...] No se puede considerar a la obra contemporánea como un espacio por recorrer (donde el "visitante" es un coleccionista). La obra se presenta ahora como una duración por experimentar, como una apertura posible hacia un intercambio ilimitado. (Bourriaud 13-14)

Estas apreciaciones sobre performance y lenguaje performativo dejan, sin embargo, abierta una cuestión que, en el caso de la(s) textualidad(es) de Bruzzone, es fundamental, es decir ¿cuánto y qué queda de este lenguaje del cuerpo, expresado por el cuerpo, contingente, cambiante, experiencial e intersubjetivo cuando se traslada a la página escrita?

Desde el punto de vista teórico, ¿es posible pensar en un acercamiento al texto, consciente de los aportes de la crítica genética, que en vez de buscar instancias textuales anteriores a aquella publicada busque puntos de contacto y disyunción entre dos textos que, aunque autónomos, configuran un continuum narrativo?

La lectura analítica de Campo de Mayo que se proporcionará en los próximos párrafos se llevará a cabo intentando contestar a estas preguntas a través de una reflexión sobre el papel del dinamismo corporal en la forma y en el contenido de la novela para encontrar enlaces entre la misma y su hipotexto performativo.

\section{De la performance a la novela: Campo de Mayo (2019)}


En el pasaje desde la performance hacia la novela, lo primero que se destaca es que, contrariamente a su hipotexto performativo, Campo de Mayo muestra los rasgos de "imaginería ficcional", típicos del estilo narrativo de Bruzzone, que Keizman justamente señala ausentes en la conferencia performática.

De hecho, la narración se centra en el personaje de Fleje, un hombre que se muda con su mujer en las cercanías de Campo de Mayo, comprando una casa con el dinero cobrado por la indemnización estatal que se le entrega al ser hijo de desaparecidos, sin estar consciente de la proximidad con el lugar donde por última vez se vio su madre con vida. Después de la lectura de un libro en el cual un corredor relata su experiencia $\mathrm{y}$, de alguna manera, proporciona algunas apreciaciones teóricas sobre el acto de correr, Fleje decide empezar a entrenarse en un gimnasio, bajo la supervisión de un entrenador de apodo 'el Vikingo', para algún día empezar su actividad de corredor, recorriendo las rutas de Campo de Mayo. Sin embargo, este día tarda en llegar, hasta que, de repente, Fleje se acuerda de la cercanía del Campo gracias a un helicóptero que, al regresar a la guarnición militar, vuela sobre su casa. Desde aquel momento Fleje empieza sus carreras, primero alrededor del Campo y después en las rutas que lo cruzan. No se trata, sin embargo, de una normal actividad deportiva: Fleje corre descalzo y por un tiempo no bien especificado, pero que se intuye ser extremadamente largo, y con un preciso objetivo: buscar a su madre desaparecida. Aunque la búsqueda es el motor de la carrera, en su recorrido el protagonista encuentra varios sujetos que, por una u otra razón, están relacionados con el territorio del Campo y que, de alguna manera, desvían su misión. Paralelamente la mujer de Fleje descubre estar embarazada, pero el protagonista sospecha que el padre sea el Vikingo, entonces, después de un intento fallecido de volver a su casa, decide seguir en su carrera para buscar a su madre, esta vez en un prostíbulo. Convencido de haberla encontrada, los éxitos de la supuesta reunión dejarán Fleje tan desilusionado que su única opción, al final de la novela, será volver en el Campo de Mayo. 
Ya desde este esbozo del argumento de la novela se pueden elaborar algunas reflexiones, especialmente si se relaciona Campo de Mayo con otros textos de Bruzzone. Como ya se mencionaba, la novela mantiene un núcleo temático que proviene de la experiencia biográfica del autor, para luego virar en una dirección marcadamente ficcional, inclusive tiñéndose de sugestiones fantásticas. El hecho de que este cambio pase cuando el protagonista cambia de lugar (desde su barrio hacia Campo de Mayo) establece un inmediato vínculo con la novela quizás más conocida del autor, Los topos (2008), en la cual pasa lo mismo: la narración empieza en tonos realistas y autoficcionales, pero cuando el protagonista se traslada de Buenos Aires a Bariloche la narración ‘desvía' hacia la ficción.

En este procedimiento narrativo que establece vínculos entre Campo de Mayo y Los topos (pero también con algunos cuentos de 76 y con la novela Las chanchas) se destacan algunas peculiaridades de la novela que, si bien no cortan el enlace con las obras anteriores de Bruzzone, matizan el texto y le confieren una tonalidad que sin duda es, hasta ahora, un unicum en la escritura del autor. Estas peculiaridades tienen que ver con el nacimiento de la novela en la forma de la performance, y con la importancia que adquiere la dimensión corporal tanto en la forma como en el contenido de Campo de Mayo, hasta tal punto que el dinamismo se configura como núcleo fundacional y armazón del texto. Toda la estructura narrativa se construye al rededor del movimiento del cuerpo del protagonista, que, como se verá, terminará siendo la única y verdadera marca ontológica de su subjetividad: Fleje es porque corre, y sólo en la carrera puede intentar encontrar respuestas sobre su madre, sobre sí mismo y sobre su experiencia. Bruzzone en Campo de Mayo plantea una epistemología del cuerpo que no se funda en la dimensión sensorial de exploración del mundo a través de la corporalidad, sino en la tensión dinámica de un cuerpo que es totalmente inmanencia, totalmente en el presente, aunque cuando reflexiona en el pasado, o incluso intenta buscar maneras de sanar las heridas que este último ha dejado. Todo en la novela converge en un presente que se actualiza con cada pisada del protagonista, como si Bruzzone hubiera transformado la enunciación del Ego teorizada por Benveniste (1997) en 
algo como una 'movimentación' de un yo que afirma su existencia no al decirse, sino al moverse. En las teorías de Benveniste el sujeto existe en la medida en que, al emplear el lenguaje, entrega significado al pronombre 'yo':

Yo no puede ser definido que en términos de "locución", no en términos de objetos, como lo es un signo nominal. Yo significa "la persona que enuncia la presente instancia de discurso que contiene yo". Instancia única por definición, y válida nada más en su unicidad. (Benveniste, Problemas 173)

El origen de la consistencia ontológica del sujeto es entonces el lenguaje, más específicamente la función pragmática del lenguaje - “El enunciado que contiene yo pertenece a ese nivel o tipo de lenguaje que Charles Morris llama pragmático, que incluye, con los signos, a quienes lo usan" (172-173) — alrededor de la cual se organizan todos los otros signos lingüísticos (especialmente los pronombres ${ }^{14}$ ), que remiten no a la situación contingente, sino al mismo acto de enunciación:

Es, con todo, un hecho a la vez original y fundamental el que estas formas "pronominales" no remitan a la "realidad" ni a posiciones "objetivas" en el espacio o en el tiempo, sino a la enunciación, cada vez única, que las contiene y hagan reflexivo su propio empleo. (175)

La consecuencia de este razonamiento es que "es identificándose como persona única que pronuncia yo como cada uno de locutores se pone sucesivamente como "sujeto"” (175).

\footnotetext{
${ }^{14}$ Sin embargo, también "la 'forma verbal' es solidaria de la instancia individual de discurso por ser siempre y necesariamente actualizada por el acto del discurso y estar en dependencia dc este acto" (176)
} 
A pesar de que la fundación del sujeto como tal aparezca así resuelta en la dimensión inmanente de la enunciación, el filósofo italiano Giorgio Agamben, en su reflexión sobre las teorías de Benveniste, señala como este acto enunciativo está marcado por una "negatividad irreducible"15 (Agamben 113), radicada precisamente en su adherencia al presente del acto lingüístico:

La subjetividad, la conciencia, en las que nuestra cultura creyó encontrar su base más firme, se fundamentan sobre lo más frágil y precario que hay en el mundo: el evento de la palabra; pero este lábil fundamento se reafirma - y vuelve a caer - cada vez que ponemos en funcionamiento la lengua para hablar. (113-114)

Este doble movimiento constante entre afirmación y caída del sujeto en el presente conlleva otro gran problema:

Más aún: el viviente que se ha vuelto absolutamente presente a sí mismo en el acto de enunciación, al decir yo, rechaza atrás en un pasado sin fondo sus vivencias, ya no puede coincidir inmediatamente con las mismas. La instancia en el puro presente del discurso escinde irreparablemente la presencia a sí mismas de las sensaciones y de las vivencias en el mismo momento en que las refiere a un centro de imputación unitario. [...] Por esta razón la subjetivación, el producirse de la conciencia en la instancia del discurso, es a menudo un trauma cuya curación les resulta difícil a los seres humanos; por eso el frágil texto de la conciencia se rompe y se borra incesantemente, dejando a la luz la brecha sobre la cual está construido, la constitutiva desubjetivación de cada subjetivación. (Agamben 114)

La paradoja es evidente: cada vez que un sujeto se afirma a sí mismo cae en la trampa de cumplir también, en el mismo acto, con la acción contraria. La única

\footnotetext{
${ }^{15}$ Las citas del volumen de Agamben están traducidas por el autor.
} 
verdadera posibilidad de resolver este estallido se encuentra, siempre según Agamben, en la aproximación. Un sujeto nunca estará en condición de afirmar completamente a sí mismo, sólo podrá aproximarse al vacío cognoscitivo donde necesariamente permanece aquella "sustancia soñada" (113) que es la subjetividad.

En el caso de la novela de Bruzzone estas reflexiones resuenan significativamente: el sujeto protagónico, Fleje, existe, como ya se comentó, sólo en virtud de su dimensión corporal dinámica, concretizada en el acto de correr. Pero si es verdad que en el movimiento Fleje se afirma a sí mismo, este acto 'ontologicamente fundacional' sólo se actualiza en el presente de la carrera, borrando con cada pisada aquellas anteriores. En este sentido el pasado sólo permanece como huella, en la interpretación derridiana del término, es decir una imposibilidad de presencia, o, mejor formulado, imposibilidad de volver presente algo en su plenitud y concreción. En las teorías de Derrida esta huella se concretiza en el signo escrito, sin embargo, en el caso de Bruzzone no es la escritura que deja huellas, sino el cuerpo. Otra vez una paradoja: un cuerpo que corre para afirmar su existencia, y que, mientras lo hace, de alguna manera genera una no-existencia.

Más aún, si se considera que el protagonista corre para buscar — de una manera muy peculiar y multifacética, que se comentará en el próximo párrafosu madre desaparecida, la aproximación no sólo es la única posible resolución (suponiendo que pueda haberse una resolución) de la búsqueda, sino también la clave de lectura de todo lo que Bruzzone narra en la novela, es decir de todas las etapas de este proceso de búsqueda imposible. El movimiento de Fleje deja así de ser hacia la madre y se convierte en una carrera para acercarse lo más posible a la mujer, sin poderla encontrar definitivamente debido al hecho de que de ella sólo quedan las huellas, las no-presencias.

Desde este punto de vista es altamente significativo que Fleje pare muy pocas veces su carrera después de su comienzo, y más aún que cuando lo hace esta suspensión corresponda a momentos de estallido de su trayectoria existencial. La falta de la madre sólo se puede medir en la dimensión dinámica del movimiento, único recurso a disposición de Fleje para aproximarse al no-lugar donde queda la 
mujer. Cada vez que el protagonista para, se fija inevitablemente en la dimensión espacio-temporal y contingente del presente, que excluye cualquier posibilidad de contacto con la figura materna.

Para dar mayor evidencia de cuanto apenas mencionado, y también para profundizar estas perspectivas, es oportuno considerar los diferentes núcleos temáticos de la novela singularmente, investigando la importancia del dinamismo corporal y de sus significados más profundos en cada uno de ellos.

\section{Genealogías quebradas}

\section{La búsqueda imposible}

Como ya se mencionó, la novela empieza un día en que el protagonista, viendo un helicóptero que sobrevuela su casa y dirigiéndose hacia el Campo de Mayo, decide empezar a seguirlo y a recorrer corriendo el largo perímetro del lugar.

La aparición del helicóptero desencadena una reacción inmediata e instintiva que tiene que ver con la desaparición de la madre, como si el vuelo de regreso del helicóptero representara la vuelta de la madre al lugar de su detención: "Fleje se mudó, sin saberlo, a cinco cuadras de donde desapareció su madre. Ahora, entonces, corre en su busca. Campo de Mayo está cerca, y su madre, piensa Fleje, muy lejos no debería estar" (Bruzzone, Campo pos. 32). ${ }^{16}$

Fleje empieza a correr con el preciso objetivo de buscar a la mujer, aunque sabe que se trata de una búsqueda imposible, y, durante toda la novela, sigue corriendo por un periodo que el autor nunca detalla, pero que se intuye ser extremadamente largo (más de un año).

Bruzzone pone en escena, como ya hizo en sus novelas anteriores, la deriva de la búsqueda de padres que no se pueden encontrar, y lo hace a través de la imagen de un cuerpo que corre infinitamente, que persigue un objetivo inalcanzable.

\footnotetext{
${ }^{16}$ La indicación de la posición se refiere a la edición ebook Kindle de Campo de Mayo.
} 
Pero, y aquí está la verdadera originalidad de la novela, la carrera, al representar la búsqueda, encarna también el posible encuentro con la madre. Fleje, de hecho, corre descalzo, y lo hace por varias razones: la primera es para someterse a una forma de dolor físico que le permita, de alguna manera, entender el dolor padecido por las víctimas de tortura detenidas en el Campo bajo dictadura:

Con esto, Fleje se pregunta si acaso no son lo mismo (o al menos si no son cosas significativamente similares) las torturas y vejaciones que sufrieron todos esos hombres, mujeres y niños en los campos de exterminio (alrededor de 5.000 personas, de las cuales los sobrevivientes pueden contarse bien, porque son pocos) que el martirio al que él mismo se somete, en el mismo lugar, ahora que corre sin detenerse. (pos. 237)

Además, Fleje tiene el deseo de pisar con sus pies la última tierra que su madre pisó con vida (y, casi seguramente, ella también descalza), pero al mismo tiempo la falta de informaciones sobre el destino del cuerpo materno lleva el protagonista a sospechar (o, por lo menos, a no excluir la hipótesis) de que la madre no fue echada al mar en un vuelo de la muerte, sino enterrada en el Campo, así que el contacto directo de la piel con el suelo donde quizás está su madre significa para el protagonista la posibilidad de entrar en contacto físico con la mujer, de alguna manera encontrarla y tocarla:

Pero en el caso de Fleje, además, esto de correr descalzo tiene un componente adicional. No tanto por lo que significó entrenar sus pies para algo que nunca habían hecho (lo que nos lleva a pensar otra vez en las torturas, en los centros de exterminio y en los carniceros que, como el exsargento Víctor Ibáñez, administraban toda aquella masacre) [...] Lo que hay en la cabeza de Fleje, además de la pasión por correr, es haberse enterado, a pocos días de mudarse a la casa en la que vive, frente a la plaza del barrio Teniente Ibáñez, que su madre estuvo en uno de esos centros de 
exterminio de los que habla el exsargento Víctor Ibáñez. Con lo que, claramente, este sería, en realidad, el verdadero punto brillante de la historia. Un punto brillante que, por otro lado, es muy oscuro. Muy probablemente, según el mismo corredor ha investigado incluso desde antes de empezar a correr, su madre haya estado en ese campo de exterminio conocido como "El campito". Con lo que correr descalzo, así, no es solo estar a la moda, estar a tono con las torturas que tuvieron lugar en el lugar por donde corre, sino pisar la tierra que, según Fleje sospecha, fue la tierra que pisó su madre por última vez, seguramente descalza. (pos. 252-261)

Correr descalzo significa entonces realizar una búsqueda que a la vez ya es encuentro, un encuentro que se realiza totalmente en la dimensión corporal, tanto por imitación como por contacto, con una madre que, al ser enterrada, se vuelve una especie de fuerza telúrica (y, también, magnética), una verdadera madre (en la) tierra, cuya memoria sólo se concretiza en la dimensión física del contacto y del movimiento.

Sin embargo, este contacto, esta fusión casi pánica con la memoria materna, queda en una dimensión hipotética, y el mismo protagonista expone su carácter falaz cuando declara su convicción de que la madre en realidad haya sido asesinada en un vuelo de la muerte:

Por otro lado [...], puesto que en Campo de Mayo hay un aeropuerto, y puesto que está comprobado que desde ese aeropuerto del que hoy salen los helicópteros que cada tanto hacen temblar ventanas y paredes y techos del barrio Teniente Ibáñez y de tantos barrios vecinos salían muchos de los llamados "vuelos de la muerte", Fleje no cree con demasiado énfasis en que su madre esté enterrada en algún lugar de Campo de Mayo. Ella, casi con total seguridad, fue subida a uno de esos aviones y fue arrojada al mar. (pos. 263) 
Otra vez Bruzzone pone en escena una búsqueda paradójica, que se arma y desarma constantemente, en la cual el protagonista está a merced de una carrera que ya no es él a conducir, sino que lo controla totalmente, que le quita cualquier percepción del paso del tiempo y lo atrapa en un recorrido circular que sigue repitiéndose sin establecer un destino final, casi como si el protagonista fuera un satélite de este lugar estático y amenazador que es el Campo de Mayo, definitivamente configurado como el otro personaje protagónico de la novela.

Fleje sigue entonces recorriendo el perímetro del lugar, dándose cuenta sólo esporádicamente del paso del tiempo. La carrera, imagen del cuerpo en movimiento par excellence, se vuelve así síntoma de una condición de continua repetición y, por ende, estática, una búsqueda sin resultado, una voluntad de encuentro y reconstrucción de los lazos familiares frustrada.

\section{La familia quebrada}

El quiebre de los vínculos familiares se convierte de esta manera en otro tema fundamental de la novela que, a partir del núcleo temático de la imposible búsqueda de la madre, irradia en todo en texto. De hecho, aunque Fleje consiga entrar en el Campo de Mayo para seguir con su carrera al interior del lugar, después de un periodo de permanencia no bien precisado se verá obligado a salir cuando uno de los personajes que encuentra le comunica la noticia del embarazo de su mujer.

A la muerte de la madre se contrapone entonces una nueva vida, la del hijo de Fleje. Sin embargo, como la primera no tiene una confirmación efectiva al no saberse cuál fue el destino final de la mujer, también la posibilidad de un rescate 'contra' la muerte que representa la noticia del embarazo no tiene un inequívoco fundamento en la realidad. De hecho, el protagonista, aunque decida volver a su casa, no regresa por la felicidad, sino por la sospecha de que el hijo no sea suyo, que el verdadero padre sea 'el Vikingo', el vecino de casa con el que Fleje se 
entrenó antes de empezar su carrera. Otra vez, como ya pasó en Los topos, el quiebre del vínculo de filiación no sólo atañe a la generación anterior, sino se proyecta hacia la sucesiva: la paternidad de Fleje es frustrada por la sospecha de la verdadera identidad del padre de su hijo, como en Los topos aquella del protagonista era negada por la decisión de su mujer de abortar (aunque en realidad se descubre que era una mentira y que el bebé nació). Bruzzone pone en escena hijos que no logran encontrar una reparación del trauma de la ausencia de los padres, ni siquiera en el acto simbólico de crear un nuevo vínculo familiar asumiendo ellos mismos el papel de padre.

Más aún, el regreso empieza a demorarse cuando Fleje, siempre corriendo, sube a un tren. Supuestamente el tren debería ser el extremo opuesto del Campo de Mayo: una heterotopía, ${ }^{17}$ un lugar abierto, dinámico y proyectado hasta un destino que se sitúa en un futuro cercano y alcanzable.

Sin embargo, al subir al tren Fleje no para su carrera, y mientras corre en el vagón, especialmente cuando lo hace contramano al sentido de marcha, empieza a razonar en las teorías del espacio-tiempo y en cómo su carrera en el tren pudiera realmente influir en el las mismas, volviendo eterno un momento que debería pasar muy rápidamente. El hecho de que Fleje consiga básicamente transformar en inmóvil un espacio que, tradicionalmente, es la movilidad por definición es otra vez síntoma de la parálisis que atrapa su vida después de la desaparición de la madre. Su carrera sigue siendo estática, aunque sea dinámica, y el estatismo del viaje en el tren es la enésima frustración de la posible paternidad de Fleje, cuyo regreso al hogar sigue demorándose.

Más aún, en este espacio definitivamente contradictorio del tren, el regreso a casa no sólo se demora, sino se desvía completamente cuando Fleje encuentra a una joven, Sami, con la que empieza a hablar y de la que rápidamente se enamora. Otra negación de la posibilidad de reanudar los lazos familiares: en vez de elegir a

\footnotetext{
${ }^{17}$ Con el término 'heterotopía' Foucault ("Espacios”) designa aquellos lugares reales, estructurados como espacios definidos, pero diferentes de todos los restantes espacios sociales, donde estos últimos están contemporáneamente representados, contestados y derramados. La función de estos espacios, en relación con los otros, es de compensar, neutralizar o purificar los mismos.
} 
su mujer, Fleje se deja llevar por sentimientos inmediatos e instintivos y elige quedarse con la joven.

También Sami está en el tren con un objetivo preciso: buscar a militares disfrazados. La relación entre la joven y el protagonista empieza entonces en la superposición de otra búsqueda a aquella de la madre y del futuro hijo. De hecho, los dos empiezan a estudiar los pasajeros del tren para averiguar la posible doble identidad de ellos, hasta que las discusiones entre los dos llevan Fleje a sospechar que el vecino que supone ser el verdadero padre del hijo de su mujer también sea un militar. Sami, que Fleje intuye ser una 'matamilitares' (estableciendo así un inmediato lazo intertextual con la figura de Maira, la travesti 'matapolicías' de Los topos), se propone ayudarle a averiguar esta teoría yendo a la casa del Vikingo, pero nunca regresa. Si en un primer momento Fleje sospecha que él le hubiera hecho daño, no tardará mucho en descubrir la verdad: Sami se ha enamorado del hombre y ha decidido quedarse con él, quizás en una relación poliamorosa que involucra también a la mujer del protagonista.

\section{(Des)encuentros desmitificadores}

Fleje entonces fracasa en su vuelta al hogar y a la familia, ingresa otra vez al Campo, sin un destino y sin un objetivo. De repente encuentra a un hombre excavando un pozo. Lo primero que se le ocurre a Fleje es pensar otra vez en su madre y su hipotética sepultura en el Campo:

Al ver al principal con su pozo, Fleje se pregunta (una vez más, porque estas preguntas son las que vuelven siempre) si su madre y sus amigos desaparecidos habrán cavado los pozos de sus propias tumbas y si acaso andan enterrados por ahí. (pos. 891) 
Después de varios días en los que los dos no hablan mucho (Fleje le cuenta de su madre pero el principal no muestra interés), una noche el hombre decide comunicar al protagonista algo que él seguramente no sabe:

Luego, el principal va al tema del que quería hablar: cuenta que en Campo de Mayo todavía hay gente detenida. Fleje al principio no le cree. [...] Pero el principal insiste. Dice que ahora no torturan a los detenidos para pedirles información, sino para que guarden silencio. Los tormentos se detienen cuando el cautivo no habla más, no grita, no se mueve. Todos los días lo mismo. Al que grita lo torturan muchísimo, al que hace silencio, solo unos golpes. (pos. 906-909)

Sin embargo, el principal cambia rápidamente de argumento, para quejarse de su hija, que trabaja como prostituta. Hasta que un día el hombre aparece más contento y le relata a Fleje de que internó a la muchacha en un prostíbulo. La noticia desencadena en Fleje una reacción inmediata:

Fleje, que quizá esperaba algo más, se apaga un poco. Pero al tiempo vuelve a encenderse. Porque el principal, un día, dijo que hay gente viva, que el ejército todavía tiene gente viva. Y Fleje asocia. Piensa en su madre. ¿Y si estuviera viva, encerrada en un puterío? (pos. 926)

La búsqueda se desvía así otra vez y adquiere definitivamente el carácter paródico y desmitificador típico de la narrativa de Bruzzone.

Fleje decide ir a buscar a su madre en el prostíbulo mencionado por el principal. Inmediatamente el narrador presenta el carácter paradójico del lugar: los hombres no pagan directamente para tener encuentros sexuales con las mujeres que trabajan allí, sino para desafiarlas a un partido de billar, y sólo si lo ganan logran acostarse con las prostitutas. El hecho de que estas mujeres sean expertas jugadoras, y que entonces casi siempre ganen los partidos y muy raramente tengan que 
acostarse con los clientes, configura el prostíbulo como otro lugar tramposo en la novela. Así como el tren es estático y el hogar es quebrado por la supuesta traición de la mujer de Fleje, el prostíbulo también contradice su estatuto tradicional y se convierte en un lugar donde son las prostitutas que explotan a los hombres, y no al revés.

Fleje se convence de que su madre está en este prostíbulo y, en efecto, encuentra una prostituta que parece tener la misma edad que tendría la mujer si todavía estuviera viva ("Estima que su madre debe tener entre 60 y 65 años" pos. 967). Para el protagonista la identificación es inmediata, esa mujer es su madre, y no importa que ella en varias ocasiones le diga que nunca tuvo hijos:

Entonces, al verla (al reconocerla, más bien) Fleje le dice a su madre que es su hijo.

-No tengo hijos - dice ella.

Es una mujer que no parece muy vieja. Ahora que están frente a frente, jugando al pool, Fleje la ve tan parecida a lo que siempre vio en las fotos que guarda que no puede creer lo poco que su madre envejeció en tanto tiempo. (pos. 998-1000)

Fleje decide desafiarla a un partido para monopolizar su atención, convencido de vencer y poder así reanudar el vínculo quebrado con la supuesta madre. Sin embargo, el protagonista sigue perdiendo, gastando completamente su dinero y hasta llegando a robar a los pasajeros del tren para poder seguir jugando. Sólo cuando juega su último partido, completamente desmoralizado y listo para renunciar a su búsqueda, vence. Bruzzone pone otra vez en escena la falacia del proceso de búsqueda: cuanto más el sujeto se compromete, más su compromiso lo atrapa en una espiral descendiente hacia la derrota. Es sólo en la dimensión de la casualidad y del azar que la búsqueda logra llegar a un resultado, aunque siempre de alguna manera inacabado y, en última instancia, falso. 
La negación, en el caso de Campo de Mayo, se produce cuando, después de haber ganado, Fleje decide tener una relación sexual con la mujer. Su objetivo, en realidad, no es llegar al acto, sino desenmascarar la verdadera identidad de la prostituta que, al acercarse físicamente a él, supuestamente su hijo, no podrá seguir adelante por el instintivo asco del acto incestuoso:

Ahora Fleje mira a su madre y trata de convencerla de que él es su hijo. Claro que ella lo niega tanto que él mismo termina por dudar de sus propias certezas. ¿Qué hacer? Intentar coger con ella. Fleje está seguro de que, llegado ese momento, ambos se darán cuenta de quién es quién. (pos. 1020)

Sin embargo la prostituta no se niega, la relación se realiza, e incluso la mujer empieza a hacerse pasar por la madre durante el acto para satisfacer a Fleje:

Fleje no tiene mayores inconvenientes en coger con su madre. Es una mujer de carne firme a pesar de la edad, de labios gruesos, flexible y soñadora. Tan soñadora como él. Ella, durante el acto sexual, para satisfacer, al fin, la fantasía de Fleje, decide hacerse pasar por la madre. (pos. 1042)

El hecho de que Fleje no tenga problemas en acostarse con la supuesta madre remite otra vez al prisma de la aproximación como clave interpretativa de la búsqueda paródica puesta en escena por Bruzzone: la posesión del cuerpo materno, ya de por sí imposible si no en proyecciones edípicas y en este caso completamente negada en virtud de la muerte de la mujer, sólo puede concretizarse en la posesión de un cuerpo parecido, entre la prótesis y el doppelgänger, pero que nunca será aquel cuerpo definitivamente perdido.

La actitud paródica, 'mutante', incorrecta e irreverente de Bruzzone llega a su cenit en esta escena, que además dialoga estrechamente con los otros textos del 
autor, especialmente Los topos: si en la primera novela el hermano apropiado se identificaba con la figura de una travesti, mientras el padre con un torturador, ahora este árbol genealógico quebrado y paródico se completa con la madre-prostituta.

Es interesante reflexionar sobre estas tres correspondencias. Al caracterizar las dos figuras familiares proporcionadas por Los topos, el hermano y el padre, Bruzzone se sirve de la identificación paródica para amplificar de alguna manera rasgos de las mismas: de hecho el hermano apropiado, en virtud de su estatuto incierto (¿nació o no nació, está vivo o muerto, es hombre o mujer?), se identifica con la figura de la travesti, mientras el padre, que en el texto se intuye haber sido el que habló con los militares, sellando el destino de la madre, se convierte en un torturador. En contraposición, Campo de Mayo, al establecer la correspondencia madre-prostituta, proporciona un discurso diferente: ahora no se trata de una amplificación paródica de las características de la mujer, sino de la traducción en imagen textual, siempre en clave paródica, de la aporía que implica cualquier búsqueda de un padre desaparecido. Al superponer dos figuras de por si antitéticas se pone en escena la falacia de una búsqueda que siempre se revela tramposa y, básicamente, inconcluyente.

Si a este discurso añadimos la negación de la posibilidad de cumplir el papel de padre que padecen ambos los protagonistas de las dos novelas, queda definitivamente claro lo que ya se mencionó anteriormente: la marca ontológicotemporal de estos sujetos sólo puede ser el presente. No es posible reanudar vínculos con el pasado, pero tampoco se puede postular una proyección hacia el futuro, el quiebre impuesto por el trauma de la ausencia quita ambas opciones y deja los sujetos en un presente que no hace nada más que reiterar a sí mismo. ${ }^{18}$

${ }^{18}$ En realidad, el protagonista de Los topos logra proyectarse hacia un futuro, pero puede hacerlo sólo en la relación de violencia y control con su torturador, y además esta posibilidad se concretiza después de que él, como el supuesto hermano, se ha convertido en travesti. La posibilidad de pensar en un futuro se alcanza entonces sólo al despojarse de su identidad de hijo de desaparecidos y a través de la parodia y de la paradoja. 


\section{El espacio del Campo}

\section{Movimientos satélites}

La otra gran temática de la novela es la peculiar conexión que el protagonista establece con el espacio de Campo de Mayo, cuyo fundamento ya se adelantó en los párrafos anteriores: Campo de Mayo fue el lugar de detención y desaparición de la madre de Fleje.

La presencia del campo es una constante en toda la novela (no acaso la denominación del lugar llega a su título) desde el comienzo, cuando el protagonista se muda sin saberlo en sus cercanías, hasta el final. Si bien la conexión entre el protagonista y el sitio es antes que nada afectiva, siempre en la novela se evidencia también el posicionamiento físico de Fleje con respecto al lugar. De hecho, la primera parte de Campo de Mayo, al relatar el entrenamiento y el comienzo de la carrera, corresponde al acercamiento físico de Fleje al lugar. Ya en este primer momento, cuando el protagonista todavía no interactúa directamente con el espacio del campo, la fundamental ambigüedad de su conexión con el sitio es evidente: Campo de Mayo es un lugar de muerte, es el lugar de LA muerte para el protagonista al ser el espacio que marcó definitivamente el destino de su madre como desaparecida y el suyo de huérfano, pero al mismo tiempo Fleje siente la necesidad de conocer, intelectual y físicamente, el lugar. Las razones de esta atracción, de este verdadero magnetismo que el lugar ejerce sobre el protagonista, son las que ya se analizaron anteriormente: recorrer el lugar y pisar la tierra del campo significa buscar y quizás encontrar a la madre perdida.

Sin embargo, esta trayectoria 'hacia la madre' en un primer momento se demora porque Fleje sólo recorre el perímetro del lugar sin ingresar. Este movimiento 'satélite' tiene una duración extremadamente larga y no exactamente especificada (se intuye que Fleje siga corriendo alrededor del campo por meses), aunque, en los planes del protagonista, no debería haber sido tan extensa. La voluntad de Fleje al comienzo de su carrera es aquella de dar una vuelta alrededor 
del campo y después ingresar. Sin embargo, se dará cuenta de haber superado el punto de partida de su carrera cuando ya está casi a mitad de la segunda vuelta, decidiendo entonces completarla. Este esquema se repite muchas veces, así demorando el ingreso. Bruzzone aquí pone en escena las dificultades y las incertidumbres que complican el comienzo del proceso de búsqueda puesto en marcha por los hijos de desaparecidos. Fleje se encuentra en una situación estática porque no consigue gestionar su carrera y parar el recorrido donde quiera, aunque en efecto esté corriendo. La carga metafórica que Bruzzone confiere a esta imagen desemboca otra vez en la paradoja: un personaje que corre pero que se encuentra en una situación de parálisis existencial. El autor, detrás de esta imagen concreta y corporal, pone en escena las dudas que atrapan el protagonista sobre la posibilidad de encontrar a la madre en el campo, sugiriendo también que en este primer momento de la búsqueda él no esté todavía listo para lo que pueda encontrar (o no encontrar) en el lugar.

Es interesante también reflexionar sobre la cuestión de la duración de este primer momento y, sobre todo, del hecho de que Fleje no se dé cuenta de su larga extensión. El tiempo linear de la historia es completamente desplazado por otra temporalidad, centrada en el sujeto, circular hasta el punto de perder comienzo y final, terminando por volverse siempre igual a si misma. Esta temporalidad 'urobórica' ${ }^{19}$ es otra señal de la parálisis que atañe al protagonista en el comienzo de su trayectoria en la novela: el tiempo fluye, pero de manera que Fleje no se da mínimamente cuenta de lo que pasa, fijándose sólo en la repetición consecutiva del mismo acto.

\section{El ingreso al campo}

\footnotetext{
${ }^{19}$ El úroboro es un símbolo que muestra a una serpiente que engulle su propia cola y que forma un círculo con su cuerpo. El úroboro simboliza el tiempo eterno, cíclico y circular, pero también la lucha eterna y el esfuerzo inútil, ya que cada vez que el recorrido circular termina vuelve a empezar. La carrera de Fleje en este momento de la novela es 'uróborica' precisamente porque, a pesar del esfuerzo del protagonista, sigue siendo igual a sí misma, sin modificaciones y entonces sin avances.
} 
La piedra angular de este círculo vicioso se encuentra en un momento específico de la novela durante el cual, mientras que Fleje sigue corriendo, empieza a llover. La formación de un grande charco en el camino recorrido por el protagonista lo lleva a desviar de su ruta y, de repente, a ingresar al interior del Campo de Mayo.

No es casual que este cambio se realice durante un temporal: en toda la narrativa de Bruzzone el agua siempre es una poderosa imagen textual que se relaciona con la memoria, el sueño y, muchas veces, con la muerte (Basile 140). Cuanto apenas mencionado se exhibe de manera extremadamente manifiesta en la casi totalidad de los cuentos que constituyen 76, como también en algunos momentos de Las chanchas.

La recurrencia de imágenes acuáticas en la narrativa de Bruzzone es una constante referencia a la suerte que le tocó a las víctimas de la dictadura militar, inclusive sus padres, muertos porque (casi seguramente) lanzados en las aguas del Río de la Plata desde los aviones militares. La diseminación de estas imágenes en los textos es síntoma de un trauma que impregna la vida de los personajes y, detrás de ellos, del autor.

El hecho de que Fleje ingrese al Campo de Mayo bajo la lluvia es entonces otra señal del significado que Bruzzone entrega al lugar: el ingreso en el sitio de cautiverio y muerte de la madre es parecido a una especie de catábasis, un viaje en lugar de la muerte, un descenso a un 'inframundo' donde quizás encontrará a la madre:

Fleje imagina que, del mismo modo que él, muchos otros están de incógnito en Campo de Mayo. Y que Campo de Mayo es, en realidad, un lugar para estar de incógnito. Su madre, por ejemplo, y las 5.000 personas que el Ejército Argentino llevó hasta allí para hacerlas desaparecer, de alguna forma, también estuvieron de incógnito. (pos. 292) 
Sin embargo, la mujer no está: lo único que Fleje encuentra son militares que intentan atraparlo y cuya presencia amenazadora le obliga evitar los senderos trazados en el campo para en cambio recorrer rutas secundarias, desviando otra vez de sus planes originales.

En este nuevo recorrido Fleje encuentra varios sujetos, algunos que aparecen esporádicamente (como por ejemplo los rugbiers que se entrenan en Campo de Mayo bajo un régimen de disciplina parecida a aquella de los militares) y otros que en cambio vuelven a aparecer varias veces durante su carrera. En particular el protagonista encuentra dos hombres, tocayos (apodados 'José 1' y 'José 2'), que permanecen en el campo por razones diferentes: uno trabaja en un jardín y entra en el Campo para cultivarlo, mientras el otro es un paleoartista que sueña con realizar una reserva ecológica en el lugar, y que entonces se dedica a una serie de investigaciones sobre el suelo y las posibilidades que este ofrece. Ambos parecen entrar y salir del Campo, sin embargo, Fleje los encuentra muy a menudo durante sus recorridos, sugiriendo que, en realidad, los dos se quedan constantemente en el sitio de la misma manera que el protagonista, sin poder salir: "Fleje sabe que él no es un desaparecido. Tampoco lo son José 1 ni José 2. Sin embargo, sospecha que estar en Campo de Mayo es como ser invisible. O, quizá, que Campo de Mayo en su totalidad es en cierta forma invisible” (pos. 327).

El Campo de Mayo exhibe definitivamente su rostro siniestro, herencia del pasado dictatorial que sigue en el presente, convirtiéndose en una especie de estómago que digiere quien ingresa en sus fauces y lo desaparece exactamente como durante los años de la dictadura, en el mismo lugar, desaparecieron miles de personas por manos de los militares.

Es precisamente uno de estos dos personajes, “José 1", el que se dedica a la jardinería, que trae a Fleje la noticia del embarazo de su mujer, impulsando así su salida del Campo.

\section{Trayectorias corporales}


Desde que Fleje ingresa en el interior del campo, además, se produce un cambio que convierte el dinamismo de la carrera desde la circularidad repetitiva hasta un movimiento centrípeto. De hecho, el protagonista se mueve paulatinamente desde los confines externos hacia el interior de Campo de Mayo, permitiendo así que a través de sus ojos Bruzzone pueda proporcionar una precisa descripción de los diferentes espacios del sitio. De esta manera el lector descubre que en la enorme superficie de Campo de Mayo no sólo funciona una guarnición militar, sino también el basural central de la CEAMSE, ${ }^{20}$ un polígono de tiro, escuelas, un Hospital Militar, un geriátrico, espacios de eventos y una planta de tratamiento de efluentes.

El Campo entonces se configura como un espacio multifacético donde conviven diferentes instancias de experiencia humana, desde lo lúdico hasta lo sanitario, desde la escuela, proyección hacia el futuro, hasta la guarnición militar, donde resuenan ecos de un pasado de muerte.

Sin embargo, Fleje sólo cruza de manera tangente estos lugares oficiales y oficializados, realizando la mayoría de su recorrido en los espacios no regulados del Campo: los senderos secundarios, los bosques y, especialmente, el basural y el vertido de aguas residuales de la ciudad, cuya carga simbólica tiene que ver con el hecho de que se trate de lugares donde confluye todo lo que se tira y olvida de la vida cotidiana y que, al mismo tiempo, Fleje se entere de una teoría según la cual estas partes del Campo fueron excavadas por los prisioneros militares bajo dictadura, o que directamente fueron empleadas como fosas comunes. El interés de Fleje para estas zonas del Campo tiene que ver con estas teorías y con la sospecha de que quizás allí está enterrado el cuerpo de la madre:

Correr por ahí es como buscar a su madre entre la basura. En realidad, como el relleno sanitario comenzó a realizarse en los últimos años de la dictadura, y como los vuelos de la muerte no eran la única práctica asesina

\footnotetext{
${ }^{20}$ La Coordinación Ecológica Área Metropolitana Sociedad del Estado (CEAMSE) es una empresa pública que se ocupa de la gestión de los residuos sólidos del Área Metropolitana de Buenos Aires.
} 
en aquel tiempo, Fleje se permite pensar que su madre (y otros) podrían estar ahí, bajo décadas de basura acumulada. (pos. 339)

Pero, como ya se comentó largamente, la búsqueda nunca llega a un resultado y siempre conlleva trampas. De hecho, el protagonista, aunque pueda postular que la madre esté enterrada en el basural, se da cuenta de lo que este hecho significaría:

Si la madre de Fleje hubiera sido enterrada ahí abajo, toda esa basura acumulada, todo lo peor de la basura, y su propia madre habrían terminado en las napas, y a través de ellas en el río Reconquista y en el Río de la Plata y en el mar. (pos. 348)

Más aún, no sólo la búsqueda sigue siendo falaz, sino también sigue desviándose muy fácilmente. El ejemplo más evidente es cuando Fleje se entera del embarazo de su esposa: el movimiento invierte su dirección y se vuelve centrífugo. El protagonista empieza así su supuesto regreso al hogar que, como ya se ha comentado, nunca se realizará y será desviado primero por la presencia de Sami en el tren y finalmente por la búsqueda de la madre en el prostíbulo.

Es interesante reflexionar sobre el hecho de que, desde el comienzo de su carrera, el prostíbulo es el único espacio donde Fleje deja de correr y se detiene, primero para jugar al billar y después para acostarse con la supuesta madre. La razón de este detenimiento es bastante evidente: Fleje estaba corriendo para buscar a su madre, y ahora que está convencido de haberla encontrada no necesita correr más. Sin embargo, la situación paródica y paradójica que se crea sigila definitivamente el fracaso y la imposibilidad de un encuentro con la mujer, que ahora, y sin que haya ninguna duda más, resulta inalcanzable.

\section{La vuelta al campo}


Lo único que le queda a Fleje, fracasada también esta última búsqueda, entonces, es rendirse completamente, ingresar una última vez al Campo de Mayo y, quizás, nunca salir. Frente a la definitiva decepción el protagonista cumple un último movimiento, otra vez centrípeto y catabásico, para volver al único lugar donde todavía las posibilidades de su búsqueda no se han cerrado. Estar en el campo es la sola manera que Fleje encuentra para establecer un contacto con la madre en una superposición temporal entre pasado y presente. La derrota es total, la madre ya no está en el campo y nunca volverá, sin embargo, el protagonista encuentra en este 'estar donde estuvo ella' una manera para no parar de todo su búsqueda, sino para reactivarla, aunque sin resultados, en una eterna aproximación.

Así, en la última escena de la novela, Fleje no sólo vuelve al Campo de Mayo, sino se dirige hacia una especifica parte del sitio: el vertido de aguas residuales. Otra vez Bruzzone se sirve de imágenes acuáticas, esta vez para señalar la definitiva derrota de la búsqueda. Es interesante confrontar los dos momentos de la novela en los cuales el agua cumple su papel simbólico: cuando Fleje ingresa al Campo y empieza seriamente su búsqueda lo hace, como ya se mencionó, bajo la lluvia, mientras el sello definitivo de la derrota de la misma pasa frente a un vertido de agua sucia. La carga simbólica de ambas imágenes es bastante evidente: el comienzo de la búsqueda es señalado por la presencia dinámica del agua que cae desde el cielo, un agua que, aunque en la trayectoria de Fleje represente el ingreso al lugar de la muerte, representa también la posibilidad del nacimiento de nueva vida; el final, en contra, proporciona la imagen de un agua estancada, podrida, un lugar tóxico lleno de residuos, un lugar inadecuado para la vida.

Sin embargo, aunque Fleje se dirija en el lugar más siniestro del Campo de Mayo, la Judeca de este infierno engullidor, frente a este lago estancado de residuos repugnantes, un verdadero Cocito moderno, pasa algo que, de alguna manera, deja entrever una posibilidad de rescate para el protagonista.

Mientras Fleje está sentado en la orilla de este lago, de repente, aparece una tortuga en el agua sucia. Durante la novela ya había sido mencionada la cuestión de la presencia de tortugas en el vertido, especialmente por el paleoartista, sin 
embargo, el protagonista siempre liquida la cuestión como leyenda urbana, sin darle ningún peso. El hecho de que, en realidad, la presencia de la tortuga confirme esta creencia tiene un significado fundamental para el protagonista: si en este lugar hay un animal que no debería estar allí, y además que nadie de verdad cree poder encontrar allí, esto significa que quizás también la madre, que no debería estar en ningún lugar al ser desaparecida, todavía se puede encontrar.

Además, acercándose, Fleje se da cuenta de que los ojos del animal están cubiertos por unos velos blancos. Se trata de un animal ciego que, de alguna manera, logró sobrevivir en medio de la mugre gracias a su olfato: la hediondez del agua se convierte así en una especie de brújula que le permite orientarse distinguiendo los varios olores que la componen. La imagen de la tortuga, entonces, resignifica aquella del agua: no se trata más de un charco tóxico y mortífero, sino de un lugar habitable, donde poderse orientar y donde vivir basándose no en la racionalidad, sino en la concreción de un cuerpo que, a través de los sentidos, se vuelve instrumento epistemológico para comprender el mundo y orientarse en ello.

La novela se cierra así con una imagen vital, de esperanza, que deja abierta al lector la decisión sobre el destino del protagonista, parado frente a una encrucijada: hundirse completamente en la catástrofe del sentido o aceptar su condición de desamparo, así como la tortuga se adapta a la contaminación de su agua.

\section{(In)Conclusiones}

Después de haber considerado las principales temáticas de la novela se puede entonces reflexionar sobre las preguntas que han orientado todo el análisis de Campo de Mayo: ¿qué pasa en el pasaje desde el hipotexto-performance hacia el hipertexto-novela? ¿hay elementos que se quedan?

Sin duda, es más sencillo empezar a contestar a estas preguntas desde la perspectiva opuesta, es decir considerando lo que se pierde en la 'novelización' de la performance. Porque algo inevitablemente se pierde. La conferencia 
performática es centrada en la viva voz del autor que relata su experiencia personal, sin crear personajes literarios detrás de los cuales disfrazarla, y esta inmediatez seguramente falta en la novela. Falta también la coralidad de los testimonios recogidos por Bruzzone en sus tránsitos por Campo de Mayo, que en la novela se condensan en la voz de un narrador que habla de estos sujetos y que, aunque devuelva sus palabras a través del recurso al discurso directo, siempre funciona como mediador en este acto de restitución.

Sin embargo, estas faltas, fisiológicas en el pasaje de un medio expresivo a otro, no significan que en Campo de Mayo no se queden muchos otros aspectos de la conferencia performática. Bruzzone es capaz de construir una narración que mantiene intacto el dinamismo y la corporalidad que caracterizan el hipotexto, y lo hace tanto a nivel formal, a través de varios recursos lingüísticos (frases recurrentes que funcionan como una especie de metrónomo y confieren al texto el ritmo de la carrera del protagonista, verbos de acción constantemente reiterados y narración en presente, como si los acontecimientos estuvieran pasando en el instante de la lectura), como a nivel de contenido, al construir toda la narración al rededor de la tensión dinámica del cuerpo de Fleje en movimiento, un movimiento que se origina en la voluntad de acercamiento a la figura materna, pero que, debido a su carácter inalcanzable, siempre y sólo queda en la perpetua aproximación, única dimensión posible para este imposible encuentro.

Más aún, el personaje de Fleje, aunque creado específicamente para la novela y sólo postulado sin nombre en la performance, está construido de una manera extremadamente peculiar, que sin duda remite a su origen en la dimensión performativa. De hecho, Bruzzone no da mucha información sobre la vida del protagonista antes del comienzo de su carrera, el lector sólo sabe lo que es necesario para entender los acontecimientos de la novela, es decir que la madre de Fleje desapareció, que él cobró una indemnización estatal con la cual compra la casa en las cercanías del Campo, que está casado y que antes de su carrera se entrenó con el Vikingo. Nada más se dice sobre su pasado, su vida, su trabajo. Esta escasez de datos sobre el protagonista tiene dos consecuencias principales. Primero, que Fleje 
existe sólo en el presente de los acontecimientos narrados en la novela, y básicamente existe en cuanto cuerpo en movimiento: “¿Qué piensa Fleje? No lo sabemos. A veces piensa una cosa, a veces piensa otra. Por ahora, corre. [...] Piensa en su madre, probablemente. $\mathrm{Y}$ en que, si quiere sobrevivir, es mejor estar en movimiento" (pos. 269-272).

Segundo, que todo lo que no es proporcionado por el narrador sobre el protagonista es dejado a la inferencia personal del lector. Este último es entonces testigo directo y activamente involucrado en la construcción ontológica del personaje de Fleje, y al mismo tiempo, testificando directamente su búsqueda en su devenir, participa también a la trayectoria epistemológica del protagonista. Ambos rasgos, una ontología y una epistemología compartida entre narrador, personaje y lector, son rasgos detectados como típicos de la performance.

Por estas razones, en conclusión, podemos afirmar que Campo de Mayocon su amplia red hipertextual y su estratificación interna de significados - es una novela dinámica, es decir una novela que encuentra en el dinamismo corporal el pivote de sus significados y de sus significantes, en una estructura narrativa sin duda novelesca, pero con contornos difuminados que hacen que las rígidas barreras entre géneros tan distintos como la novela y la performance pierdan de significado y se abran hacia una fructífera hibridación.

Más aún, si consideramos el final de la performance y el de la novela, cuanto apenas mencionado aparece todavía más evidente. Como se comentó, la conferencia performática termina sin cerrarse con la declaración por Bruzzone de la voluntad de escribir una novela sobre un corredor en el Campo de Mayo, sentado así las bases por Campo de Mayo-novela. A la misma manera, la novela se cierra con la única mención de un tiempo futuro, que, no casualmente, otra vez está sigilada por una imagen acuática:

Dado que la tortuga estira su cuello para olfatear a Fleje, Fleje estira su mano y le acaricia la cabeza. La tortuga, al parecer, se siente cómoda. Fleje 
también. Tranquilo, piensa, tranquilo. El pronóstico meteorológico anunció lluvia y es muy probable que vaya a llover. (pos. 1091)

Otra vez el agua, bajo la forma de la lluvia, señala un cambio en la trayectoria de Fleje. Así como Fleje entró en el Campo bajo la lluvia, ahora la posibilidad de la misma condición meteorológica, anunciada por un pronóstico (entonces por una previsión que se realiza en una temporalidad que sale de la circularidad de la carrera de Fleje para remitir a una linealidad histórica), señala la posibilidad de desarrollos futuros de la trayectoria no solo corporal, sino biográfica, de Fleje, una continuación de su carrera, transformada en narración eterna, que desafía la muerte y mantiene así en vida la madre.

Campo de Mayo termina, como la performance, sin una verdadera conclusión, lanzando una apuesta para sucesivas e hipotéticas narraciones sobre el futuro del personaje de Fleje, casi a señalar que, aunque difícil y tramposa, la búsqueda de un padre desaparecido nunca termina.

\section{Bibliografía}

Agamben, Giorgio. Quel che resta di Auschwitz. L'archivio e il testimone. Torino: Bollati Boringhieri, 1998.

Arfuch, Leonor. El espacio biográfico. Dilemas de la subjetividad contemporánea. Buenos Aires: Fondo de Cultura Económica, 2002. . La vida narrada: memoria, subjetividad y política. Villa María: Eduvim, 2018 . Memoria y autobiografía. Exploraciones en los límites. Buenos Aires: Fondo de Cultura Económica, 2013

Assumpçao, C. G. Mesa de trabajo: Performance como método de investigación. 2008.

http://www.hemisphericinstitute.org/esp/.../colombia_workgroup_16.htm 1. 17 de mayo de 2020. 
Barthes, Roland. "La muerte del autor". El susurro del lenguaje. Barcelona: Paidós, 1987, pp. 75-84

Basile, Teresa. Infancias: la narrativa argentina de HIJOS. Villa María: Eduvim, 2019.

Benveniste, Émile. Essere di parola. Semantica, soggettività, cultura. Milán: Bruno Mondadori, 2009. . Problemas de lingüística general. Madrid: Siglo XXI, 1971 [1997].

Bourriaud, Nicolas. Estética relacional. Buenos Aires: Adriana Hidalgo, 2008.

Brijaldo, Gina Carolina. "Interpretaciones íntimas sobre la escritura performativa". La palabra, núm. 24, enero - junio de 2014, pp. 111-117

Bruzzone, Félix. 76. Un clásico + dos nuevos cuentos. Buenos Aires: Momofoku, 2014 [2008]. . Los topos. Buenos Aires: Mondadori, 2008. . Las Chanchas. Buenos Aires: Literatura Random House, 2014. . Campo de Mayo. Buenos Aires: Literatura Random House, 2019, ebook Kindle. . "Campo de Mayo: cómo quebrar a un rugbier" Revista Anfibia. http://revistaanfibia.com/cronica/campo-de-mayo-como-quebrar-unrugbier/. 27 de marzo de 2020

Buisán, Andrés. "Libros: Campo de Mayo, de Félix Bruzzone". Por el país, 17 de junio de 2019. http://porelpais.com.ar/libros-campo-mayo-felixbruzzone/. 14 de mayo de 2020.

Centre de Creació del Cos I el Moviment. Glosario 03 Performatividad (según John L. Austen y Roland Barthes). 2012. http://granerbcn.cat/tag/performatividad/. 15 de mayo de 2020.

Cohen, Renato. Performance como linguagem. São Paulo: Perspectiva, 2011.

Culler, Jonathan. Literary Theory. A very short introduction. New York: Oxford University Press, 1997.

Derrida, Jacques. Margini della filosofia. Torino: Einaudi, 1997.

Foucault, Michel. "Espacios diferentes". Obras esenciales vol.I, Barcelona: Paidós, 1999, pp. 431-441 - ¿Qué es un autor? Barcelona: Ediciones Literarias, 2010.

Genette, Gerard. Palimpsestos: la literatura en segundo grado. Madrid: Taurus, 1989.

Gatti, Gabriel. Identidades desaparecidas. Peleas por el sentido de los mundos de la desaparición forzada. Buenos Aires: Prometeo Libros, 2011.

Keizman, Betina. "Las vidas que transcurren (una lectura de la performance "Campo de Mayo" de Félix Bruzzone)". TRANS-, núm. 19, 2015. http://journals.openedition.org/trans/1198. 13 de mayo de 2020.

Laddaga, Reinaldo. Estética de laboratorio. Buenos Aires: Adriana Hidalgo, 2010.

Lois, Èlida. "La Crítica genética: un marco teórico sobre la disciplina, objetivos y método". Creneida, núm. 2, 2014, pp. 57-78. 
Mattio, Javier. "Reseña de "Campo de Mayo" de Félix Bruzzone: exorcismo rasante". LaVoz, 22 de julio de 2019. https://www.lavoz.com.ar/numerocero/resena-de-campo-de-mayo-de-felix-bruzzone-exorcismo-rasante. 14 de mayo de 2020

Peller, Mariela. "(No) seguir buscando a mamá. Perfomance y posmemoria en Campo de mayo de Félix Bruzzone". Kamchatka. Revista de análisis cultural, núm. 11, Jul. 2018, pp. 419-440.

Prividera, Nicolás. Plán de evasión. 26 de mayo de 2009. http://haciaelbicentenario.blogspot.com/2009/05/plan-de-evasion.html. 22 de marzo de 2020

Sarlo, Beatriz. Tiempo pasado. Cultura de la memoria y giro subjetivo. Una discusión. Buenos Aires: Siglo XXI, 2005.

Tavani, Giuseppe. "Filologia e genetica". Cuadernos de Filología Italiana, núm. 3, 1996, pp. 63-90. 